\title{
THE IMPACT OF WOMEN EMPOWERMENT ON LEADERSHIP EFFECTIVENESS: THE CASE OF UNDP IN LEBANON
}

\author{
Farah Jabbouri \\ Beirut Arab University, Beirut, Lebanon
}

This research intends to study the influence of female empowerment on leadership effectiveness in the UNDP Lebanon. It was once believed that men were the only ones that could fill positions of power and leadership. Even nowadays, women still face great difficulties while obtaining the positions of power in their career and suffer from inequality at work. This study will be looking at the impact of women empowerment and its influence on fulfilling work outcomes and meeting organizational objectives as well as proving that gender equality is the basis of empowerment. The research utilizes mixed methods for conducting interviews and sending online anonymous questionnaires. The results of the interviews show that the UNDP strongly encourages female applicants to apply to power and leadership positions. Upon conducting the study, the distribution of jobs among men and women at the UNDP was shown to be equitable. 52\% of the employees are female and $48 \%$ are male. Furthermore, the findings show that 50\% of the employees that filled the questionnaire have female managers. The online questionnaire shows that the staff are satisfied with the empowerment initiatives at the UNDP and that both men and women are empowered equally.

Keywords: UNDP; leadership effectiveness; women empowerment; men empowerment; gender equality

\section{Background of the study}

The concept of women empowerment has been a controversial issue for decades. Some viewed women as incompetent to fill in the power positions while others assumed that women are born to undertake household tasks and should not participate in the development of society as such. Given the significant influence of globalization in most of the countries worldwide, radical changes have challenged these old beliefs. People started to realize the importance of gender equality in the development of the world.

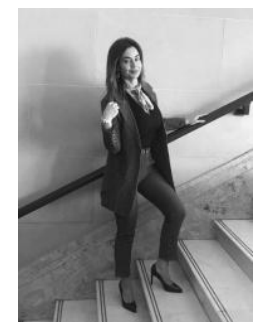

\section{Farah Jabbouri}

Doctor in Business Administration from Beirut Arab University, Lebanon Deputy director of financial affairs and active researcher in Union of Arab Banks.

Research interests : human resources, banking and finance, and management.

Email: jabbourif@gmail.com 
As suggested by Timko, K. (2017) society is normalizing male dominance, which is manifested as an unequal distribution of power between genders. Hegemony is used to define gender relationships and is often perceived as male domination. Masculinity has become a strategy to outrank women in society (Tlaiss, 2014). For example, Lebanon's sociocultural values are encouraging patriarchy, while more than 400 female managers face discrimination and sexism in recruitment, promotion \& development opportunities (Tlaiss \& Kauser, 2010).

This shows that Lebanese organizations are encouraging gender inequality and promoting male hegemony. At the same time, Lebanese women compose more than half of the population in both education and healthcare sectors. However, they are still misrepresented at the labor market and face gender discrimination at managerial levels. Oriented by the cultural cognitive principle, the Arab culture is male-controlled with men being expected to achieve career success while women being expected to stay at home focusing on family matters (Tlaiss, 2013).

\section{Problem Statement}

The increasing involvement of women in the labor force during the last decades and their ability to attain positions of leadership in management attracted research attention to the issues of gender equality in leadership. Nowadays, the society has evolved to increasingly incorporate women into the labor force and working environment. This study focuses on quantifying women inclusion in the positions of power within the UNDP. It also aims to investigate the most important challenges and facilitators for women employed by this organization. This would help to determine the UNDP's position in terms of gender-related issues and empowering women to engage in the positions of power.

The inclusion of women into the workforce added value and diversity in the nontraditional sectors and a positive relationship started to appear between the performance of organizations and the presence of women in them (Subramanian et al., 2016). However, not all organizations and companies are fully accepting the idea of women occupying leadership positions.

Despite the development in societal beliefs and mentality under the ongoing globalization and especially with the advances in technology, sociology and economic principles, there are still some discrepancies in the number of women filling the positions of headship. Power and leadership positions in many organizations are still reserved for men, even if subconsciously so, as women are not allowed or empowered enough to fill in these positions.

To determine the influence of providing opportunities and empowering women to fill leadership positions on the effectiveness of organizational performance, this research will use the case of the United Nations Development Program in Lebanon. UNDP is one of the United Nations organizations in Lebanon adopting and strongly endorsing the principle of gender equality and empowering women to gain access to leadership and power positions.

This case study will evaluate the extent of employee empowerment, specifically when it comes to women at the UNDP, trying to correlate the organization's success to its wellbuilt workflow and embracing diversity. Furthermore, this will enable us to clarify whether women act effectively in the position of leadership and power, thus resulting in improved organizational performance and effectiveness. 


\section{THE IMPACT OF WOMEN EMPOWERMENT}

\section{Research Question}

How does women empowerment at the UNDP Lebanon contribute to leadership effectiveness and success of this organization?

\section{Significance of the study}

This study contributes to the body of knowledge on the importance of engaging women in leadership positions within organizations. Furthermore, it helps with rectifying the old beliefs of classifying positions according to gender. This study also aims to highlight the importance of gender equality, equal opportunities, and empowerment in the workplace, by studying the case of the UNDP. The goal is to clarify that women, just like men, can hold the positions of leadership in an institution and this diversity in leadership contributes to an organization's success.

\section{Empirical studies on female leadership}

In theory, both genders must have the same educational opportunities, rights, and work opportunities. On the other hand, the inferior position of many women proves that social inequality is shaping the position of women in terms of economic, social, and political powers and suggesting that women must have the full access to power opportunities, just like men.

The feminist ideas globally refer to the belief that women and men deserve the same opportunity, social rights, respect, and treatment. In this context, the theory strives to limit social inequality based on gender which over the past offered a greater opportunity for men as compared to women.

The ongoing globalization of business has increased the diversity of the workforce and raised the challenges organizations are currently facing, strategically and culturally, in their decision-making process to maintain success and competitiveness. Effective decision-making is crucial for any organization in the present context as the wrong decision could have a severe impact on the success and even survival of organizations. Technology and globalization raised the standards of competition along with a new factor which is the increasing number of females integrating into the workforce structure, thus increasing importance of retaining female talents in organizations (Hasin et al., 2018).

The percentage of professional women entering the workforce is currently the same to the percentage of men, while the rate of women in managerial positions is still very low. Back in 2007 only 12 females were able to reach the level of chief executive positions. The recent data reveals that women are accounting for half of the total workforce, while they only constitute $37 \%$ of the lower and middle management and only $26 \%$ of the senior management (Taneja et al., 2012).

Increasing the strength of women in the top-level management positions is becoming an increasingly important issue for organizations. Abdo, N. \& Kerbage, C. (2012) stated that companies must increase the number of female employees in the middle and top management positions to help balance the workforce structure which should sustain gender diversity at every organizational level.

Retention of female employees, their satisfaction as employees, and the impact of women on profits and productivity are crucial for organizations. Successful employers are always reevaluating the retention strategies to keep up competitiveness. In this context, 
organizational leaders must focus on the motivational and empowerment factors to retain female talents which have been a predictor for higher profits with the increased number of women executives.

Chrlier et al. (2007) conducted a study on the companies which represent women in their executive positions revealing that those were able to demonstrate better financial performance than the other companies, where there is less representation of females in management.

Furthermore, another study discussed the financial performance of companies according to the percentage of women in the top managerial positions between 1998 and 2000, considering numerous control variables including the type of industry and company size, and revealing that those with higher percentage of female top managers demonstrate better financial performance.

Previous research studies have revealed that women are the biggest global economic opportunity exceeding China and India combined. A research carried out back in 2009 revealed that women earned $\$ 13$ bln which was double to the GDP of China and India. In this context, institutions are increasingly realizing the influence of women on the economy as the next market opportunity (Patel, 2013).

\section{Females control the majority of consumer spending}

Several previous studies have revealed that women control more than $64 \%$ of the global consumer spending. The increasing presence of women in the top positions will be an advantage for the organizations trying to better understand consumer preferences and market demand. In this context, organizations must consider the opportunity of increasing market share and entering new markets which can be achieved with higher diversity in the leadership approach (Patel, 2013).

Previous literature has also revealed that women are increasingly creating their own wealth through income, savings, and earnings from own businesses. The current situation suggests an increase in successful women self-employment with fast growth of their companies (Patel, 2013).

Women are seen to enhance corporate performance. Previous studies revealed that the representation of women in the top-level positions had a significant positive impact on corporate performance through increased equity, profit, and return. The research also revealed that a minimum of three women on the board gave the best results for organizations (Patel, 2013).

The previous literature revealed that investment in women leaders has large effects on the welfare and GDP of the next generations. A previous study has also shown that GDP is increasing with the entrance of female participants to the economy (Patel, 2013).

Furthermore, the research revealed that women spend more of their money on the investment in health and education which will directly affect the welfare of the next generations and offer resilience (Patel, 2013).

The previous literature revealed that the number of female graduates is increasing and is already exceeding the number of men graduates (in some countries). This proves the importance of female job candidates for the success of organizations through taking advantage from the development of their talents (Patel, 2013). 


\section{THE IMPACT OF WOMEN EMPOWERMENT}

\section{Gender Equality and Empowerment}

Studying gender empowerment we must differentiate between the concepts of sex and gender. By "women" here we do not refer to gender, but rather to a group of people. It is not so much about the biological distinctions between women and men, but about the way culture gives sense to such differences in femininity and masculinity, and to the dominance hierarchy between them.

Given the difference between women and men, empowerment is to be described as "a mechanism whereby those denied the right to make strategic decisions on life obtain the ability to do so" (Klingborg \& Moore, 2006). Thus, the aim of the empowerment is to improve women's capacity to lead their lives in a changed gender partnership.

Furthermore, empowerment is also about a transition mechanism that involves both the issue of what "improvements" are and the question of "how" they are measured. There are three dimensions of empowerment: capital, organization, and accomplishments. Empowerment is about reducing constraints to people's abilities to take decisions regardless of the actual choices made. This implies that the final outcomes for each gender is not an issue if they are able to freely make their own decisions.

During the 2005 United Nations Millennium Development Goals Study (MDG), the late Kofi Annan, Secretary General of the United Nations (1997-2006), stated that "full participation of women in all levels of policy making is fundamental human rights", and that women have a fundamental position in development. Gender disparities in schooling, political engagement and job prospects should be minimized, not only because it is fair, but also because it would have positive implications on many other aspects of society, in other words, the overall performance would be increased.

Accordingly, Kofi Annan argued in the same article that the equality between men and women is also the precondition for the accomplishment of other MDGs. For example, better schooling could have a positive impact by strengthening the awareness about utilizing contraceptives and managing homes in addition to raising children. He also believed that promoting women in other, narrower ways would also affect their capacity to take part in decision-making.

Education is the first element of empowerment, since economic independence has many advantages within households. Women with more schooling receive higher salaries because it is easier for them to get a career and participate in household expenses. Then families would be more willing to invest in women's education since it would yield higher returns for them eventually. Moreover, as women take part in household expenditures, their part in decision-making would increase as well.

Consequently, special measures to educate girls are required, primarily because teaching girls would have major spillover effects. Furthermore, the importance of financial empowerment for women has been grounded by (Ngcobo, 2016) who showed that decline in domestic violence and overall women's empowerment in India was the product of microfinance funding development. In fact, in real life, communities are neither governed by some sort of a tyrant, it is rather that members of a family tend to have varying expectations and conflicting view on certain topics, such as how many children the household can afford, each suggestion is assigned a different weight based on the knowledge and negotiation strength of the family members (whether it is the wife, husband, eldest son, etc.). 
For example, some demographic and health studies (DHS) showed that girls/women often desire less children than their husbands. Consequently, the mean number of children per household may be lower if women could use contraceptives regardless of their husbands.

Thus, most of the studies on this concept show that gender equality is a major subject that has far reaching consequences on the whole of society, not only women. Furthermore, most of the authors agree that empowerment cannot be accomplished without gender equality. Therefore, there exists a linear positive relationship between empowerment and gender equality.

\section{Target Population}

The population of this study consists of the UNDP Lebanon staff amounting to 155 people in total. At the UNDP, women are playing a central role in achieving gender equality and promoting sustainable development.

Women are one of the main contributors in a national economy, and they act as important producers of food, and also managers of natural resources. Additionally, women are the main providers of unpaid care and domestic work globally since women do 2.6 times more of the unpaid care and domestic work than men.

The UNDP works hard to include women in leadership of all forms and in decisionmaking. This includes taking part in the political office, administration, private and local sectors, contributing to disaster risk reduction, peacebuilding, conflict prevention and recovery under post-crisis. On the UNDP job application site, the organization states that it strongly encourages female candidates at any of the listed vacancies for any position type. Furthermore, the UNDP will not conduct any interviews if there are no female applicants among the candidates. In this manner, the UNDP seeks to empower and encourage women to participate. The success of the UNDP's operations in Lebanon will not be achieved without the hard work of the employees and the investment in human resources.

This is strongly related to the empowerment of female employees and candidates and the extent of women engagement in the decision-making process (https://www.lb.undp.org/content/lebanon/en/home.html).

The UNDP Lebanon is well known for promoting gender equality and women empowerment as a main tool to achieve operational and institutional success. For this reason, the UNDP believes that empowering women and enhancing their ability to undertake leadership positions contribute to the success of the whole organization.

This approach is crucial and it became possible for the UNDP because of their strong belief in women's capabilities and strengths that contribute to the overall success of the organization. Therefore, the UNDP regularly organize trainings for women and employees in general, to empower them and provide them with the opportunities to be effective members in the workplace and be the beacons for change and improvement.

\section{Sampling Procedure}

The size of our sample is 80 people (that is, $52 \%$ of the total employee number at the UNDP in Lebanon). The sample data was initially taken from the list of employees made up of executives and project managers. The sample size was chosen due to the purposive sampling technique which targets those employees who are directly involved in leadership positions at the UNDP Lebanon. 


\section{THE IMPACT OF WOMEN EMPOWERMENT}

Table 1 - Sample Size

(Source: author's own field work)

\begin{tabular}{|c|c|c|c|}
\hline Sample categories & Population size & Sample size & $\begin{array}{c}\text { Sample size as \% of the } \\
\text { population size }\end{array}$ \\
\hline Executive managers & 5 & 2 & 40 \\
\hline Project managers & 50 & 30 & 60 \\
\hline Senior project officers & 100 & 48 & 48 \\
\hline Total & 155 & 80 & 52 \\
\hline
\end{tabular}

\section{Cross-Tabulations}

\begin{tabular}{|c|c|c|c|c|c|}
\hline & \multicolumn{4}{|c|}{$\begin{array}{l}\text { Women empowerment within an organization improves } \\
\text { diversity among personnel }\end{array}$} & \multirow[t]{2}{*}{ Total } \\
\hline & Agree & Disagree & Neutral & $\begin{array}{c}\text { Strongly } \\
\text { Agree }\end{array}$ & \\
\hline Female & 20 & 0 & 4 & 25 & 49 \\
\hline Male & 11 & 1 & 2 & 17 & 31 \\
\hline Total & 31 & 1 & 6 & 42 & 80 \\
\hline
\end{tabular}

Referring to the above cross-tabulation, 20 female respondents agreed that women empowerment within an organization improves diversity among personnel, 4 stated that they are neutral, and 25 stated that they strongly agree.

On the other hand, 11 male respondents agreed that women empowerment within the organization improved diversity, while 1 disagreed with this statement. 2 stated they were neutral and 17 stated that they strongly agree.

\begin{tabular}{|c|c|c|c|c|c|}
\hline & \multicolumn{4}{|c|}{$\begin{array}{l}\text { What is the level of management responsiveness within } \\
\text { your organization? }\end{array}$} & \multirow[t]{2}{*}{ Total } \\
\hline & High level & $\begin{array}{c}\text { Neutral } \\
\text { level }\end{array}$ & $\begin{array}{l}\text { Low } \\
\text { level }\end{array}$ & $\begin{array}{c}\text { Moderate } \\
\text { level }\end{array}$ & \\
\hline Female & 14 & 1 & 3 & 32 & 50 \\
\hline Male & 15 & 1 & 0 & 14 & 30 \\
\hline Total & 29 & 2 & 3 & 46 & 80 \\
\hline
\end{tabular}

Referring to the above cross tabulation, 14 female respondents stated that the level of management responsiveness in their organization is high, while 1 respondent stated that it is neutral. Also, 3 of them stated that it is of low level, and 32 stated it is moderate.

On the other hand, 15 male respondents stated that the level of management responsiveness in the organization is high while14 of them stated that the management responsiveness is moderate.

\section{Correlation Analysis}

Seeking to identify the relationship between women empowerment and leadership effectiveness at the UNDP, Pearson moment correlation method is utilized. Pearson 
coefficient, $r$, can take any value between -1 and +1 , where 0 to 0.29 refers to a weak positive correlation, 0.3-0.49 refers to a moderate positive correlation and 0.5-1 refers to a strong positive correlation. Regarding the negative relationship, 0 to -0.29 refers to a weak negative correlation, -0.3 to -0.49 refers to a negative moderate correlation and -0.5 to -1 refers to a strong negative correlation. The dependent variable is leadership effectiveness and the independent variable is women empowerment.

The components of the dependent variables (leadership approaches) are management efficiency, communication, and management responsiveness.

The components of independent variables (women empowerment) are participation in decision-making and gender equality.

The hypotheses are formulated as follows:

H1: There is a correlation between women empowerment and leadership effectiveness at the UNDP.

$\mathrm{H} 0$ : There is no correlation between women empowerment and leadership effectiveness at the UNDP.

$\mathrm{H} 2$ : If a relationship exists between women empowerment and leadership effectiveness at the UNDP, it is a positive relationship.

H0: If a relationship exists between women empowerment and leadership effectiveness at the UNDP, it is a negative relationship.

The table implies the presence of a moderately to strongly positive correlation of the value between 0.29 and 0.65 between women empowerment and management efficiency, communication among employees, teamwork participation, strong decision-making, high management responsiveness and high level of gender equality meaning. This clarifies that encouraging women and empowering them by the provision of all necessary trainings had a lot to do with leadership effectiveness at the UNDP.

This result allows the study to accept both $\mathrm{H} 1$ and H2. Regarding the significance analysis, the results show that the $\mathrm{P}$ value of teamwork participation of women is 0 , thus revealing that women participation is one of the significant components of empowerment and has a great influence on leadership effectiveness. 


\section{THE IMPACT OF WOMEN EMPOWERMENT}

Table 2 - Women empowerment and leadership effectiveness

(Source: author's own field work)

\begin{tabular}{|c|c|c|c|c|c|c|c|}
\hline & & 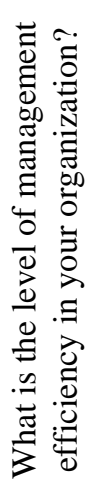 & 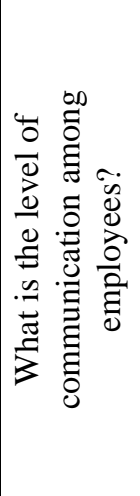 & 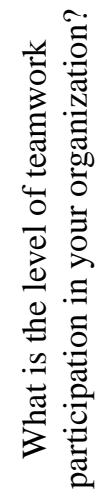 & 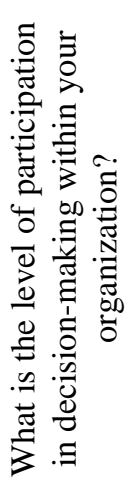 & 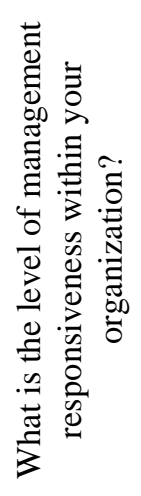 & 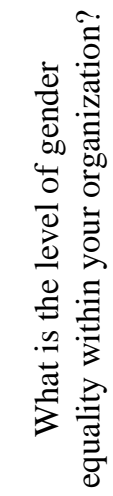 \\
\hline \multirow{3}{*}{$\begin{array}{l}\text { What is the level of } \\
\text { management efficiency in } \\
\text { your organization? }\end{array}$} & Pearson Correlation & 1 & .154 & -.060 & $.431^{* * *}$ & $.331^{*}$ & .149 \\
\hline & Sig. (2-tailed) & & .282 & .674 & .002 & .018 & .295 \\
\hline & $\mathrm{N}$ & 51 & 51 & 51 & 51 & 51 & 51 \\
\hline \multirow{3}{*}{$\begin{array}{c}\text { What is the level of } \\
\text { communication among } \\
\text { employees? }\end{array}$} & Pearson Correlation & .154 & 1 & $.583^{* *}$ & .173 & $.326^{*}$ & -.059 \\
\hline & Sig. (2-tailed) & .282 & & .000 & .225 & .019 & .679 \\
\hline & $\mathrm{N}$ & 51 & 51 & 51 & 51 & 51 & 51 \\
\hline \multirow{3}{*}{$\begin{array}{l}\text { What is the level of } \\
\text { teamwork participation in } \\
\text { your organization? }\end{array}$} & Pearson Correlation & -.060 & $.583^{* * *}$ & 1 & $.302^{*}$ & .107 & .102 \\
\hline & Sig. (2-tailed) & .674 & .000 & & .031 & .455 & .475 \\
\hline & $\mathrm{N}$ & 51 & 51 & 51 & 51 & 51 & 51 \\
\hline \multirow{3}{*}{$\begin{array}{l}\text { What is the level of } \\
\text { participation in decision- } \\
\text { making within your } \\
\text { organization? }\end{array}$} & Pearson Correlation & $.431^{*}$ & .173 & $.302^{*}$ & 1 & $.424^{* * 6}$ & .010 \\
\hline & Sig. (2-tailed) & .002 & .225 & .031 & & .002 & .943 \\
\hline & $\mathrm{N}$ & 51 & 51 & 51 & 51 & 51 & 51 \\
\hline \multirow{3}{*}{$\begin{array}{l}\text { What is the level of } \\
\text { management responsiveness } \\
\text { within your organization? }\end{array}$} & Pearson Correlation & $.331^{*}$ & $.326^{*}$ & .107 & $.424^{* *}$ & 1 & -.182 \\
\hline & Sig. (2-tailed) & .018 & .019 & .455 & .002 & & .202 \\
\hline & $\mathrm{N}$ & 51 & 51 & 51 & 51 & 51 & 51 \\
\hline \multirow{3}{*}{$\begin{array}{l}\text { What is the level of gender } \\
\text { equality within your } \\
\text { organization? }\end{array}$} & Pearson Correlation & .149 & -.059 & .102 & .010 & -.182 & 1 \\
\hline & Sig. (2-tailed) & .295 & .679 & .475 & .943 & .202 & \\
\hline & $\mathrm{N}$ & 51 & 51 & 51 & 51 & 51 & 51 \\
\hline
\end{tabular}

\section{Men empowerment and leadership effectiveness}

Seeking to identify the relationship between men empowerment and leadership effectiveness at the UNDP, Pearson moment correlation is utilized. The dependent variable is leadership effectiveness and the independent variable is men empowerment.

The table above shows that a moderate to strong positive relationship exists between men empowerment and management efficiency, communication among employees, teamwork participation, strong decision-making, high management responsiveness and high level of gender equality at the UNDP of ranges between 0.29 and 0.7 .

This proves that like women empowerment, men empowerment has a lot to do with leadership effectiveness at the UNDP. This result shows that a relationship exists between men empowerment and leadership effectiveness and this relationship is positive.

The significance analysis shows that teamwork participation significance is of value 0 . This reveals that men teamwork participation is a significant component of men empowerment and has a positive effect on leadership effectiveness. 
Table 3 - Men empowerment and leadership effectiveness

(Source: author's own field work)

\begin{tabular}{|c|c|c|c|c|c|c|c|}
\hline & & 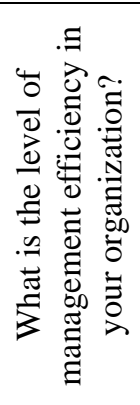 & 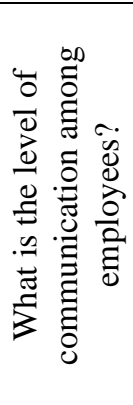 & 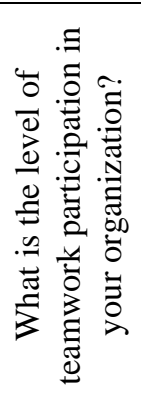 & 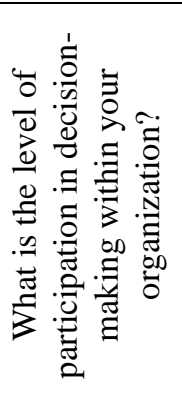 & 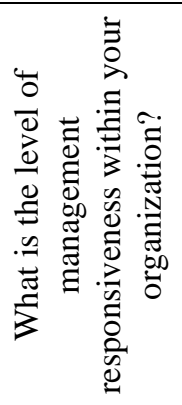 & 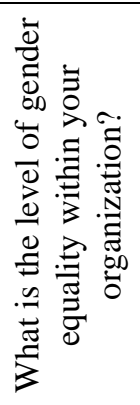 \\
\hline \multirow{3}{*}{$\begin{array}{l}\text { What is the level of } \\
\text { management } \\
\text { efficiency in your } \\
\text { organization? }\end{array}$} & Pearson Correlation & 1 & $.575 * *$ & .127 & .330 & .224 & -.051 \\
\hline & Sig. (2-tailed) & & .001 & .511 & .081 & .242 & .794 \\
\hline & $\mathrm{N}$ & 29 & 29 & 29 & 29 & 29 & 29 \\
\hline \multirow{3}{*}{$\begin{array}{l}\text { What is the level of } \\
\text { communication } \\
\text { among employees? }\end{array}$} & Pearson Correlation & $.575 * *$ & 1 & $.622 * *$ & .301 & .260 & -.043 \\
\hline & Sig. (2-tailed) & .001 & & .000 & .112 & .173 & .826 \\
\hline & $\mathrm{N}$ & 29 & 29 & 29 & 29 & 29 & 29 \\
\hline \multirow{3}{*}{$\begin{array}{l}\text { What is the level of } \\
\text { teamwork } \\
\text { participation in your } \\
\text { organization? }\end{array}$} & Pearson Correlation & .127 & $.622 * *$ & 1 & .342 & .153 & -.048 \\
\hline & Sig. (2-tailed) & .511 & .000 & & .069 & .429 & .803 \\
\hline & $\mathrm{N}$ & 29 & 29 & 29 & 29 & 29 & 29 \\
\hline \multirow{3}{*}{$\begin{array}{l}\text { What is the level of } \\
\text { participation in } \\
\text { decision-making } \\
\text { within your } \\
\text { organization? }\end{array}$} & Pearson Correlation & .330 & .301 & .342 & 1 & .360 & -.137 \\
\hline & Sig. (2-tailed) & .081 & .112 & .069 & & .055 & .479 \\
\hline & $\mathrm{N}$ & 29 & 29 & 29 & 29 & 29 & 29 \\
\hline \multirow{3}{*}{$\begin{array}{l}\text { What is the level of } \\
\text { management } \\
\text { responsiveness within } \\
\text { your organization? }\end{array}$} & Pearson Correlation & .224 & .260 & .153 & .360 & 1 & $.395^{*}$ \\
\hline & Sig. (2-tailed) & .242 & .173 & .429 & .055 & & .034 \\
\hline & $\mathrm{N}$ & 29 & 29 & 29 & 29 & 29 & 29 \\
\hline \multirow{3}{*}{$\begin{array}{l}\text { What is the level of } \\
\text { gender equality within } \\
\text { your organization? }\end{array}$} & Pearson Correlation & -.051 & -.043 & -.048 & -.137 & $.395^{*}$ & 1 \\
\hline & Sig. (2-tailed) & .794 & .826 & .803 & .479 & .034 & \\
\hline & $\mathrm{N}$ & 29 & 29 & 29 & 29 & 29 & 29 \\
\hline
\end{tabular}

\section{Gender equality and empowerment}

Most of the authors agree that gender equality is the basis for empowerment where each of men and women will feel the sense of empowerment when they feel they are granted equal opportunities. This study was able to prove this theory through the findings that reveal that staff at the UNDP Lebanon feels empowered due to the UNDP's approaches and initiatives towards gender equality.

This study was able to verify and validate the hypothesis about the existence of a positive relationship between women empowerment and gender equality verifying the point in literature. The statistical findings prove that gender equality has a strong positive influence on empowerment initiatives which drives leadership effectiveness.

On the other hand, it was verified through the interviews that the UNDP adopts the principles of gender equality on all its approaches, and empowerment is directed not only towards women but also towards men. Furthermore, it was proven that gender equality is one of the significant factors of empowerment that leads to effective communication, participation, team work as well as overall job satisfaction. 


\section{THE IMPACT OF WOMEN EMPOWERMENT}

As a result, the success of empowerment initiatives with the purpose to achieve leadership effectiveness is embedded in the gender equality approaches that the organization in question adopts as an integral part of its strategic planning.

\section{Recommendations and suggestions for further research}

The research studied the case of the UNDP Lebanon, looking closely at the relationship between women and men empowerment and leadership effectiveness. The study was able to identify different approaches to leadership effectiveness and has found that the UNDP adopts a participative leadership style that involves both men and women in the decision-making process. It encourages effective communication among all its departments and presents equal opportunities for both men and women. The percentage of women occupying leadership positions is similar to the percentage of men in the same positions, thus suggesting that the UNDP truly provides equal opportunities for both.

Considering that the UNDP has been operating in Lebanon since 1970 and has served the needs of the most vulnerable communities, strengthening the institutional capacities of ministries and municipalities in addition to many other projects, this would not have been achieved without strong organizational commitment and deployment of strong and competent teams to undertake all these operations.

Unlike all the commonly accepted beliefs that women empowerment or men empowerment alone is vital for the development of organizations, this case proves that empowerment in an organization should not be gender-based but rather it is supposed to promote all the employees based on gender equality and individual merits.

Accordingly, our research has come to formulating the following recommendations:

Every organization should consider the principle of gender equality in their recruitment approaches and team development skills.

Organizations realize the significant relationship between empowerment in general and their course of development as well as their capacity to fulfill the organizational objectives.

Organizations should invest in the skills of both men and women equally to further enhance their operations and promote a healthier workspace at the same time.

The research encourages to view employees' empowerment as a vital step for enhancing leadership and organizational effectiveness.

The research strongly recommends all organizations to initiate empowerment based on merits and skills as opposed to basing on gender.

The case of the UNDP Lebanon clarifies that trainings are essential for ensuring effective empowerment of both men and women equally. Therefore, organizations are highly recommended to include effective trainings to boost the positive impact of empowerment.

Organizations are also encouraged to draft manuals that are directed on gender equality and then to implement them in all their operations.

Organizations are highly encouraged to keep effective coordination and share ideas on women empowerment among all team members.

All organizations are encouraged to cooperate with the UN Women in Lebanon and benefit from the women empowerment initiatives they are currently adopting.

All organizations are encouraged, just like UNDP, to push for gender equality and women empowerment through including it in the procurement processes with vendors. All contracts for civil works, goods \& services provision, and any other humanitarian works in 
the scope of NGOs' work should consider how many women shall be provided opportunities and how many women shall be included into them.

\section{References:}

1. Abdo, N. \& Kerbage, C. (2012). Women's entrepreneurship development initiatives in Lebanon: Micro-achievements and macro-gaps. Gender \& Development, 20 (1), 67-80.

2. Chrlier, S; Caubergs, L; Malpas, N. \& Kakiba, M. (2007). The Women Empowerment Approach: A Methodological Guide. Commission on Women \& Development.

3. Hasin, F; Hasan, A. \& Musa, H. (2018). Women Empowerment Model: Strategies to Overcome Challenges. Journal of Fundamental and Applied Sciences, 10, 1068-1083.

4. Klingborg, D. \& Moore, D. (2006). What is leadership? Journal of Veterinary Medical Education, 33(2).

5. Ngcobo, A. (2016). Analyzing the empowerment of women leadership: A case of the Durban University of Technology. Thesis for the Degree Master of Management Science in Administration and Information Management, Durban University of Technology, Durban, South Africa.

6. Patel, G. (2013). Gender differences in leadership styles and the impact within corporate boards. The Commonwealth Secretariat, Social Transformation Programmes Division.

7. Subramanian, B., I. S. F. Irudayaraj S. \& George, S. J. (2016). Women Leadership in Organization. Indore Management Journal, 8 (2), 15-26.

8. Taneja, S; Pryor, M. \& Oyler, J. (2012). Empowerment and gender equality: The retention and promotion of women in the workforce. Journal of Business Diversity, 12 (3).

9. The United Nations Development Fund for Women (2018). Women's Empowerment Principles: Equality Means Business. United Nations Global Compact.

10. Timko, K. (2017). Gender, communication styles, and leadership effectiveness. MRPA.

11. Timko, K. (2017). Men and women are equally effective leaders. MRPA.

12. Tlaiss, H. (2015). Neither-nor: career success of women in an Arab Middle Eastern context. Employee Relations, 37(5), 525-546.

13. Tlaiss, H. \& Kauser, S. (2010). Perceived organizational barriers to women's career advancement in Lebanon. Gender in Management: An International Journal, 25(6), 462-496.

14. Tlaiss, H. \& Kauser, S. (2011). The impact of gender, family, and work on the career advancement of Lebanese women managers. Gender in Management: An International Journal, 26(1), 8-36.

15. United Nations (2007). Women in leadership roles. Division for the Advancement of Women, Department of Economic and Social Affairs, United Nations.

Paper submitted

Paper accepted for publishing

Paper published online
11 December 2020

18 February 2021

31 March 2021 